\title{
Nordic Economy Model: Principle for Economic Democracy
}

\author{
Penerapan Model Ekonomi Nordik di \\ Denmark sebagai Role Model Prinsip \\ Demokrasi Ekonomi
}

\author{
Katong Ragawi Numadi \& Fauzi Firmansyah Prakoso \\ Universitas Airlangga
}

\begin{abstract}
ABSTRAK
Globalisasi dan neoliberalisasi ekonomi ditandai dengan semakin dominannya praktikekonomi kapitalisme lintas batas negara. Pada fase ini terjadi intensifikasi proses industrialisasi sejalan dengan semakin terbukanya arus perdagangan dan investasi global. Hal ini pada kenyataanya menghasilkan dampak negatif, kecenderungan mengejar pertumbuhan dan keuntungan ekonomi mengakibatkan negara mengabaikan prinsip paling dasar dalam perekonomian yaitu kesejahteraan masyarakat. Faktanya dewasa ini distribusi kekayaan cenderung tidak berimbang yang mana kontrol ekonomi terbesar justru berada pada sebagian kecil kelompok masyarakat, sementara sebagian besar kelompok masyarakat lainnya cenderung termarjinalkan. Demokrasi ekonomi merupakan konsep alternatif terhadap perkembangan ekonomi modern. Bahwa perhatian utama adalah terciptanya kesetaraan ekonomi bagi seluruh masyarakat. Konsep ini menjadi moderasi bagi perdebatan kapitalisme dan sosialisme, bahwa keterlibatan negara harus dilakukan dalam derajat tertentu guna menanggulangi dampak negatif perkembangan kapitalisme modern. Salah satu bentuk implementasi konsepsi ini adalah model ekonomi di negara-negara Nordik. Negara-negara ini memiliki tingkat kesetaraan dan kesejahteraan ekonomi tertinggi melalui adanya sistem pengeluaran negara yang berfokus terhadap aspek sosial masyarakatnya. Salah satu wujud keberhasilan model ekonomi ini dapat dilihat di Denmark yang mana pemerintah melakukan pembiayaan terhadap seluruh kebutuhan sosial masyarakat seperti kesehatan dan pendidikan melalui sistem pajak dan pembiayaan secara kolektif.
\end{abstract}

Kata-kata Kunci: Demokrasi Ekonomi, Nordik, Denmark, Kapitalisme, Kesejahteraan

Globalization and economic neoliberalism in practice are commonly associated with a thick capitalism in the domestic economy realm. In this phase, the intensification of the industrialization process took place with the increasing issuance of global trade and investment flows. This process produces a negative impact when it pursues economic growth, and economic benefits enhancement sets aside equality as the basic foundation of economic development. More than that, in the modern economy, only a small portion of the community control the whole economic process, while most other community groups are marginalized. Economic Democracy is an alternative concept for the development of the modern economy. This concept argues that the economy should focus on the creation of economic equality for the whole community. This concept becomes a moderation for the debate between capitalism and socialism. Economic Democracy requires the state's involvement to a certain degree to overcome the negative impact of modern capitalism development. One form of implementation of this conception is the Nordik model of the economy. The Nordic countries have the highest equality and economic prosperity through a high social expenditure for their society. One form of success of this economic model is paramount in Denmark, where the government finances all community social needs such as health and education through the tax system and collective financing.

Keywords: Economic Democracy, Nordic, Denmark, Capitalism, Welfare 
Perkembangan neoliberalisme telah menghasilkan pertumbuhan perekonomian global seiring dengan semakin intensnya aktivitas ekonomi lintas negara. Akan tetapi terdapat permasalahan mengenai distribution of wealth dibalik pertumbuhan tersebut. Perdagangan bebas, keterbukaan, orientasi keuntungan dan berbagai fitur kapitalisme lainnya tidak didesain untuk mengatasi permasalahan ketimpangan ekonomi. Sistem kapitalisme secara otomatis membangkitkan adanya kesewenang-wenangan dan ketidakadilan akut hingga kemudian mengesampingkan pentingnya kesetaraan sebagai dasar dari nilai demokrasi (Pikety 2014). Bahwa benar terdapat pertumbuhan dan intensifikasi aktivitas perekonomian global, akan tetapi hanya sebagian kecil kelompok masyarakat yang terlibat dalam proses, sementara sebagian besar lainnya cenderung termarjinalkan. Berdasarkan data World Economy Forum (2015) sebanyak 71\% populasi bumi hanya menguasai $3 \%$ kekayaan dunia. Sebaliknya terdapat $0,7 \%$ masyarakat dunia menguasai lebih dari $45 \%$ dari total kekayaan dunia. Sementara itu pada tahun 2018, menurut Global Wealth Databook (2018) sebesar 44,8\% kekayaan dunia hanya dikontrol oleh $0,8 \%$ populasi masyarakat, sementara $64 \%$ masyarakat dunia hanya memiliki kontrol atas 1,9\% global wealth.

\section{Grafik 1}

\section{Piramida Global Wealth tahun 2018}

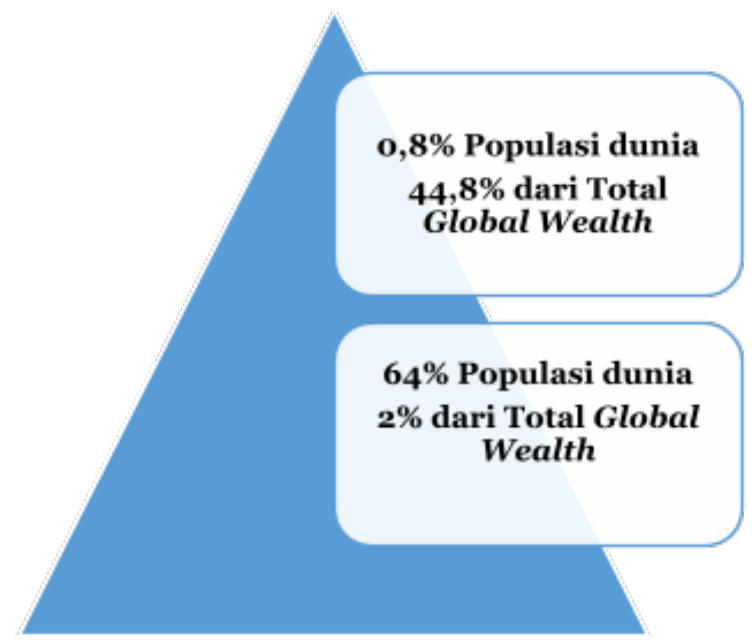

Sumber: Global Wealth Data Book (2018) 
Data diatas menunjukan adanya antitesis optimisme bahwa kapitalisme dan neoliberalisme memberikan keuntungan dan kesempatan ekonomi bagi semua. Sebaliknya justru terjadi konsentrasi kekayaan dikalangan sebagian kecil populasi global sehingga menciptakan ketimpangan ekonomi yang semakin meluas. Berkaitan dengan permasalahan distribusi kekayaan, beberapa negara mengimplementasikan prinsip demokrasi ekonomi sebagai alternatif guna meminimalisir ketidaksetaraan dan ketidakadilan dari semakin kapitalisnya iklim perekonomian global. Hal ini dilakukan dengan menciptakan regulasi baik berupa kebijakan fiskal dan moneter dalam upaya menjamin keadilan ekonomi bagi masyarakat utamanya bagi kelompok masyarakat menengah ke bawah. Salah satu role model penerapan prinsip demokrasi ekonomi adalah keberhasilan sistem ekonomi negara-negara maju kawasan Skandinavia menghadapi tantangan globalisasi ekonomi. Secara umum Negara-negara skandinavia menerapkan sebuah model ekonomi alternatif yang dikenal dengan Nordik Model of Economy sebagai kombinasi antara model perekonomian kapitalisme dan sosialisme yang mengedepankan aspek kebebasan dan keterbukaan pasar disertai dengan intervensi pemerintah dalam derajat tertentu berlandaskan prinsip kolektivitas (Andersen et al. 2007). Kombinasi keduanya menghasilkan suatu interaksi suportif dan mutual antara prinsip kolektivitas dan globalisasi ekonomi. Bahwa prinsip kolektivitas membantu penyesuaian globalisasi ekonomi sehingga memungkinkan adanya pemerataan peluang, produktivitas, dan pendapatan bagi seluruh masyarakat Negara-negara Skandinavia (Andersen et al. 2007).

Tulisan ini bertujuan menjelaskan penerapan model perekonomian Nordik sebagai perwujudan prinsip demokrasi ekonomi. Dalam hal ini penulis menggunakan sistem perekonomian Denmark dalam menggambarkan keberhasilan model perekonomian Nordik menjembatani pertumbuhan dan pemerataan ekonomi di tengah globalisasi ekonomi. Penerapan demokrasi ekonomi di Denmark merupakan proses gradual berakar dari sejarah panjang mengenai prinsip kolektivitas yang semula tumbuh dan berkembang dari dominasi kelompok sosial-demokrat sebagai kekuatan sosial-politik dan ekonomi utama di kalangan masyarakat Denmark (Lykketoft. 2009). Hal ini mengakibatkan 
kemunculan kapitalisme dan kelompok privat melalui Revolusi Industri dekade 1800 -an tidak serta merta mempengaruhi praktik kolektivitas sosial dan ekonomi di Denmark. Namun bukan berarti perekonomian Denmark menolak sepenuhnya prinsip kapitalisme, melainkan menyelaraskan ide-ide sosialisme ekonomi di tengah perkembangan kapitalisme guna menciptakan pemerataan hak dan keadilan ekonomi bagi setiap individu di dalamnya. Alhasil Denmark konsisten sebagai negara dengan tingkat perekonomian maju diikuti tingkat ketidaksetaraan ekonomi paling minim di kalangan negara-negara Eropa maupun dunia.

\section{Demokrasi Ekonomi: Alternatif Perkembangan Kapitalisme dan Ekonomi Neoliberal}

Prinsip demokrasi ekonomi berkembang dari pemahaman bahwa perkembangan kapitalisme menghasilkan ketidakadilan dan ketimpangan sosial-ekonomi yang semakin tajam di kalangan masyarakat. Dengan demikian demokrasi ekonomi bertujuan menggeser sentralisasi kekuatan ekonomi dari kelompok privat kepada seluruh masyarakat dan komunitas lokal. Seperti yang disampaikan oleh Pikety (2014) terdapat permasalahan mengenai distribusi kekayaan dalam sistem perekonomian modern yang mana perkembangan sistem kapitalisme berorientasi pada pertumbuhan ekonomi namun tidak didesain untuk memastikan terciptannya economic and social equality. Sebaliknya sistem ini membangkitkan kesewenangan oleh kelompok ekonomi dominan yang secara radikal menggerus keadilan dan kesetaraan sebagai tujuan utama perekonomian. Pemahaman dasar dalam prinsip demokrasi ekonomi berakar dari pesimisme pemikir sosialekonomi klasik seperti David Ricardo dan Karl Marx terhadap eksistensi kapitalisme. Berdasarkan fenomena sosial yang dihadapi oleh kedua nya, baik Ricardo maupun Marx melahirkan dasar pandangan kritis terhadap perkembangan distribusi kekayaan dan struktur kelas sosial. Keduannya melihat adanya dominasi kelompok sosial kecil (kaum kapitalis) mendominasi perolehan output economy, sementara sebagian besar kelompok lain yang didominasi oleh pekerja (kaum proletar) cenderung termarjinalkan (Pikety. 2014). Akibatnya era revolusi industri dianggap justru menjadi permulaan dari ketidaksetaraan ekonomi 
dalam intensitas tinggi.

Pemahaman tentang demokrasi ekonomi serta kaitanya dengan perkembangan ekonomi global juga diungkapkan oleh Malleson (2014) dalam bukunya After Occupy, Economic Democracy for the 21st Century. Menurutnya ekonomi neoliberal di era globalisasi merupakan tahapan baru dari praktik kapitalisme ditandai dengan semakin intensifnya aktivitas ekonomi lintas batas negara. Akan tetapi hal ini justru mengakibatkan disparitas ekonomi yang semakin tajam dalam masyarakat modern. Proses ekonomi di era globalisasi pada akhirnya hanya terbatas pada kepentingan kelompok elit dan korporasi global dan mengabaikan tekanan ekonomi yang dihadapi oleh sebagian besar masyarakat. Disparitas ini menurut Malleson (2014) dapat dilihat dalam tiga ranah aktivitas ekonomi. Pertama pada ranah tempat kerja yang mana sentralisasi kekuatan pemilik dan manajer dalam pengorganisasian pekerjaan dalam beberapa hal berpengaruh secara langsung terhadap minimalisasi akses keputusan dan kebebasan bagi kelompok pekerja. Kedua, terdapat kekuatan besar pemberi modal untuk memberi dan menahan kredit mengakibatkan ekonomi berkembang justru menekan kebebasan dan keadilan sosial-ekonomi masyarakat. Ketiga, berkaitan dengan kekuatan besar investor merestriksi kebebasan dan kesempatan ekonomi yang dimiliki oleh warga negara. Demokrasi ekonomi dalam hal ini menurut Malleson (2014) bertujuan menciptakan kebebasan, keadilan, dan pemerataan pada tiga ranah tersebut. Bahwa perkembangan ekonomi dewasa ini memerlukan adanya intervensi pemerintah secara menyeluruh dalam menciptakan nilai demokrasi di dalam kegiatan korporasi, struktur finansial dan investasi, bahkan terhadap berjalannya sistem pasar sehingga tercapai adanya keseimbangan distribusi kekayaan pada sektor publik.

Sejalan dengan Malleson dan Pikety, pentingnya prinsip demokrasi ekonomi juga ditekankan oleh Martin O'Neill dalam tulisannya Liberty, Equality and Property-Owning Democracy. Demokrasi ekonomi menurut O’Neill berakar dari theory of justice John Rawls yang mengkritik eksistensi ekonomi kapitalis. Terdapat tiga kritik Rawls terhadap eksistensi negara kapitalis yakni pertama, negara kapitalis gagal memberikan jaminan terhadap nilai kebebasan 
ekonomi dan politik seiring dengan kecenderungan kontrol yang hanya berada pada sebagian kecil kelompok. Kedua, perkembangan kapitalisme dianggap gagal memberikan kesempatan ekonomi yang sama terhadap seluruh kalangan masyarakat. Ketiga kapitalisme pada kenyataannya telah gagal menciptakan timbal balik ekonomi yang menguntungkan untuk semua pihak. Maka dari itu diperlukan sistem ekonomi alternatif dengan struktur kepemilikan modal serta bentuk kontrol yang berbeda dengan sistem kapitalisme yang berkembang dikalangan negara kapitalis modern dewasa ini. Penerapan demokrasi ekonomi menurut O'Neill (2009) menekankan keterlibatan otoritas negara dalam perekonomian melalui pengaturan penetapan pajak, redistribusi kapital, dan peningkatan pengeluaran negara yang ditujukan bagi perkembangan human capital utamanya perihal kesehatan dan edukasi masyarakat. Secara sederhana, demokrasi ekonomi menerima adanya kepemilikan aset dan kapital privat layaknya di negara kapitalis, namun terdapat struktur sosial masyarakat dan mekanisme institusional negara yang mampu menolak kesenjangan ekonomi akibat sentralisasi ekonomi di kalangan korporasi dan kelompok elit.

Terdapat tiga fitur utama kebijakan ekonomi dalam prinsip demokrasi ekonomi menurut O’Neill (2009). Pertama adanya pemerataan struktur kapital dalam perekonomian negara. Berbeda dengan negara kapitalis yang mana kepemilikan kapital tersentral pada individu tertentu, bagi negara demokrasi ekonomi, kepemilikan means of production terbagi secara luas dan merata di kalangan publik. Bahwa setiap individu memungkinkan untuk memiliki akses kontrol terhadap kapital produktif. Fitur kebijakan kedua adalah upaya menghambat keuntungan intergenerasional sehingga disparitas sosial-ekonomi tidak mengakar dari suatu generasi ke generasi berikutnya. Hal ini biasanya dilakukan melalui adanya regulasi kepemilikan kapital seperti tanah dan pengaturan sistem warisan termasuk pemberlakuan pajak dan berbagai bentuk regulasi lain. Ketiga adalah langkah komprehensif negara menekan angka korupsi sebagai salah satu penyebab ketimpangan ekonomi. Negara penganut demokrasi ekonomi memiliki regulasi anti-korupsi ketat untuk menutup peluang penyalahgunaan ekonomi oleh elit dan korporasi. Hal ini dilakukan melalui reformasi birokrasi, reformasi finansial, serta 
public funding terhadap elemen politik guna menghindarkan dari peluang terjadinya praktik korupsi antara korporasi dan pemerintah (O’Neill 2009). Berbagai upaya ini dilakukan dengan tujuan menghasilkan pertumbuhan ekonomi sekaligus mendorong mekanisme distribusi kekayaan, peluang, dan kebebasan ekonomi yang merata bagi seluruh masyarakat.

\section{Model Ekonomi Nordik: Perwujudan Penerapan Prinsip Demokrasi Ekonomi}

Penerapan bentuk ekonomi ideal dalam konsepsi demokrasi ekonomi dapat dilihat dari keberhasilan perkembangan dan pemerataan distribusi ekonomi di kalangan Negara-negara Skandinavia melalui penerapan model ekonomi alternatif yang dikenal dengan Nordic Model of Economy. Eksistensi model ekonomi Nordik berawal sejak masa pra-industrial yang mana negara-negara Skandinavia memiliki tiga struktur kelas meliputi kelas atas, kelas pekerja, dan kelompok petani. Seiring berjalannya waktu struktur masyarakat ekonomi semi-feudal perlahan bertransformasi menjadi affluent welfare-states yang mana jarak antar kelas perlahan semakin melebur. Salah satu faktor utama di balik kemunculan model perekonomian ini adalah dominasi kelompok sosial demokrat terutama di Swedia dan Denmark yang mengutamakan kesatuan pekerja, masyarakat kooperatif, serta perluasan hak sosial terhadap seluruh masyarakat (Iqbal dan Todi 2015). Dasar ini kemudian menghasilkan bentuk ekonomi yang merupakan kombinasi antara efisiensi ekonomi dan pertumbuhan ekonomi serta adanya harmonisasi pasar tenaga kerja dan pemerataan distribusi pendapatan. Model ekonomi Nordik menjadi distingsi tersendiri, bahwa di tengah perkembangan kapitalisme dan neoliberalisme perekonomian global, prinsip sosialisme dan kolektivisme ekonomi mampu tetap bertahan. Bahkan penerapan demokrasi ekonomi Nordik menempatkan Negara-negara Skandinavia sebagai welfare-states dengan pendapatan tinggi diikuti adanya perlindungan sosialekonomi dan distribusi berbasis egalitarian bagi masyarakatnya (Andersen et al. 2007).

Terdapat empat ciri umum dalam model perekonomian Nordik 
yang diterapkan di Denmark, Swedia, Islandia, Norwegia, Finlandia, dan Norwegia. Pertama adalah welfare-states yang memperhatikan adanya transfer dan distribusi kekayaan terhadap sektor pelayanan publik melalui pemberlakuan pajak pendapatan dan konsumsi. Kedua, pengeluaran ekonomi terbesar negara diarahkan pada sektor human capital, salah satunya adalah pendidikan, kesehatan, serta pengembangan sumber daya manusia. Ketiga adalah adanya persatuan kelompok buruh dan pekerja yang terasosiasi dengan kuat serta dilibatkan secara signifikan dalam proses perekonomian negara sebagai sarana koordinasi mengenai penentuan upah dan juga penerapan kebijakan pemerintah terhadap pasar ketenagakerjaan. Fitur umum keempat adalah adanya kebijakan collective sharing dalam derajat tinggi guna memastikan bahwa negara-negara ini bukan hanya sebagai welfare-states namun juga mewujudkan equality secara ekonomi dan sosial (Andersen et al. 2007). Adanya intervensi negara dalam aktivitas sosial ekonomi melalui penarikan pajak tinggi, proteksi sosial, dan jaminan ketenagakerjaan menjadikan sistem ekonomi semacam ini ideal diterapkan seiring dengan performa ekonomi positif yang ditorehkan negara-negara kawasan ini. Menurut Andersen (et al. 2007) keberhasilan sistem ekonomi ini setidaknya dapat dilihat melalui pertumbuhan GDP begitu juga dengan tingginya tingkat penyerapan dan level produktivitas tenaga kerja. Pada level makro, negara-negara Nordik relatif dicirikan dengan adanya keseimbangan ekonomi dengan sektor finansial publik yang kuat. Sistem ekonomi ini terbilang berhasil memadukan social equality dan economic efficiency, terbukti World Bank menempatkan Negara-negara Skandinavia pada jajaran sepuluh besar negara dengan performa ekonomi terbaik di dunia.

Secara umum model ekonomi Nordik merupakan jalan tengah perdebatan antara sistem perekonomian kapitalisme dan sosialisme. Dapat dilihat melalui Tabel 1, model ekonomi Nordik selaras dengan prinsip ekonomi kapitalisme dalam aspek pasar bebas, globalisasi, dan kepemilikan privat dalam sistem perekonomian negara. Selain itu dalam derajat tertentu, model ekonomi ini mengakui pentingnya keberadaan institusi ekonomi serta perlunya kehadiran perusahaan privat dalam ranah publik. Akan tetapi disisi lain model Nordik mengimplementasikan sisi positif dari prinsip ekonomi sosialis dalam derajat tertentu. 
Diantaranya, pemberlakuan pajak tinggi akan tetapi lebih rendah dari negara sosialisme pada umumnya. Sistem ekonomi Nordik juga menekankan kesetaraan pendapatan, persatuan kaum buruh, pemberian tunjangan pensiunan dan tunjangan pemutusan hubungan kerja, serta pengeluaran publik seperti kesehatan dan edukasi. Namun demikian tidak dalam derajat yang sangat tinggi seperti halnya negara sosialis (Iqbal dan Todi 2015). Menurut Dorfman (2018), model perekonomian Nordik merupakan antitesis sistem kapitalisme global dewasa ini, namun tidak dapat digolongkan sebagai bentuk dari sosialisme ekonomi. Perbedaan ini dapat dilihat melalui tiga aspek. Pertama, berbeda dengan negara-negara sosialis dan komunis yang dicirikan dengan performa ekonomi rendah, negara-negara Nordik memiliki perekonomian produktif dengan pendapatan per-kapita tinggi sehingga memungkinkan negara menarik pajak untuk kepentingan keuntungan sosial bersama. Kedua, berbeda dengan tingkat intervensi tinggi pemerintah dalam aspek ketenagakerjaan pada negara sosialis. Pada model ekonomi Nordik, negara memang memiliki kekuatan mumpuni dalam menciptakan regulasi ketenagakerjaan melalui peran serikat pekerja. Namun demikian tidak terdapat jaminan negara perihal output proses negosiasi dan kontrak tenaga kerja. Ketiga adalah adanya komitmen terhadap pentingnya keberadaan korporasi dan sektor privat lain bahkan terhadap aspek publik seperti fasilitas kesehatan dan edukasi.

Tabel 1

Perbedaan Kapitalisme, Sosialisme dan Model Nordik

\begin{tabular}{|l|c|c|c|}
\hline & KAPITALISME & SOSIALISME & $\begin{array}{c}\text { MODEL } \\
\text { NORDIK }\end{array}$ \\
\hline Mekanisme Pasar Bebas & Ya & Tidak & Ya \\
\hline Globalisasi & Ya & Tidak & Yas \\
\hline Tarif Pajak & Rendah & Sangat Tinggi & Tinggi \\
\hline Hak Milik Pribadi & Ada & Tidak ada & Ada \\
\hline Kesetaraan Penghasilan & Rendah & Sangat Tinggi & Tinggi \\
\hline Sistem Politik & Demokrasi & Komunisme & Demokrasi \\
\hline $\begin{array}{l}\text { Peran Lembaga } \\
\text { Ekonomi }\end{array}$ & Sangat Tinggi & Rendah & Tinggi \\
\hline Kepadatan Buruh & Rendah & Sangat Tinggi & Tinggi \\
\hline
\end{tabular}


Nordic Economy Model: Principle for Economic Democracy

\begin{tabular}{|l|c|c|c|}
\hline $\begin{array}{l}\text { Keuntungan Pensiun } \\
\text { dan Pengangguran }\end{array}$ & Menengah & Sangat Tinggi & Tinggi \\
\hline $\begin{array}{l}\text { Pengeluaran untuk } \\
\begin{array}{l}\text { Pendidikan dan } \\
\text { Kesehatan }\end{array}\end{array}$ & Menengah & Sangat Tinggi & Tinggi \\
\hline $\begin{array}{l}\text { Kehadiran Perusahaan } \\
\text { Swasta dalam Lingkup } \\
\text { Publik }\end{array}$ & Sangar Tinggi & Rendah & Tinggi \\
\hline
\end{tabular}

Sumber: Dorfman (2018)

Perkembangan globalisasi ekonomi dewasa ini dapat menjadi tantangan sekaligus keuntungan eksistensi penerapan model ekonomi Nordik. Menurut Einhorn dan Logue (2004) interdependensi dan integrasi ekonomi yang semakin masif dalam perekonomian global menimbulkan tantangan terhadap konsistensi penerapan social-welfare program dalam model perekonomian Nordik. Bahwa di era globalisasi kebijakan ekonomi Negara-negara Skandinavia berpotensi didikte oleh situasi global terutama berkaitan dengan kebijakan imigrasi, dukungan peran negara, serta pasar ketenagakerjaan. Sejalan dengan hal ini Andersen (et al. 2007) mengungkapkan bahwa berkaitan dengan globalisasi, tantangan terbesar adalah mengenai mobilitas pekerja. Kemudahan mobilitas pekerja memungkinkan terdapat kelompok masyarakat yang menikmati keuntungan sosial dan ekonomi yang diberikan negara tanpa turut serta dalam proses shared economy. Walaupun demikian disisi lain Globalisasi dapat menguntungkan karena menyediakan peluang pertumbuhan ekonomi melalui mekanisme perdagangan barang dan jasa yang semakin signifikan, mengingat adanya ketergantungan perekonomian Negara-negara Skandinavia terhadap aktivitas perdagangan internasional. Hal ini terbukti berdasarkan Nordik Regional Report (dalam Iqbal dan Todi 2015), bahwa 60\% GDP tahun 2012 Negara-negara wilayah Skandinavia bergantung pada proses ekspor dan impornya barang dan jasa terhadap negara lainnya. 


\section{Keberhasilan Penerapan Model Ekonomi Nordik di Denmark}

Di antara Negara-negara Skandinavia, Denmark merupakan role model terbaik dalam penerapan prinsip demokrasi ekonomi. Denmark hingga kini tergolong sebagai welfare-state yang mampu mengkombinasikan pertumbuhan ekonomi dan peran signifikan pemerintah mendukung terciptanya kesetaraan, keseimbangan, dan keadilan peluang serta manfaat ekonomi bagi masyarakatnya. Berdasarkan data Trading Economics pada tahun 2018 Denmark berhasil mencatatkan angka GDP mencapai 351,3 Miliar USD dengan rata-rata pertumbuhan tahunan sebesar $2 \%$ sejak tahun 2015. Angka ini menunjukan tren positif dalam perekonomian Denmark setelah sebelumnya sempat mengalami penurunan drastis pada tahun 2015. Walaupun tidak dapat digolongkan sebagai negara ekonomi besar, akan tetapi Denmark tergolong sebagai negara maju dengan perolehan GDP per kapita mencapai 62,9 ribu USD dan GDP per kapita PPP mencapai 47,6 ribu USD pada tahun 2018. Catatan tersebut menempatkan Denmark sebagai negara dengan performa ekonomi terbaik kedua di Eropa dan berada pada delapan besar dunia (Ministry of Higher Education and Science 2015). Sementara itu berdasarkan empat indikator ekonomi meliputi rule of law, regulatory efficiency, government size, dan open market, Index of Economic Freedom pada tahun 2019 Denmark berada dalam jajaran enam besar Negara Eropa dengan ekonomi terbaik serta peringkat empat belas di dunia. 


\section{Grafik 2 \\ GDP Per-Kapita Denmark}

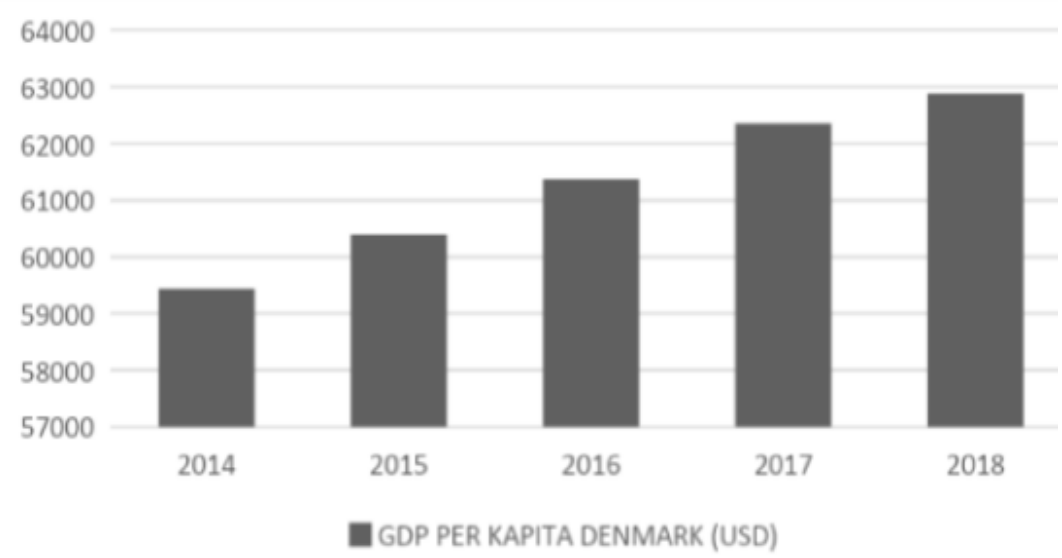

Sumber: Ministry of Higher Education and Science (2015)

Perekonomian maju juga ditunjang dengan adanya pemerataan perekonomian di Denmark. Dikutip dari data Organisation for Economic Cooperation and Development (OECD) (Dalam Grafik 3), Denmark merupakan negara dengan tingkat pemerataan pendapatan masyarakat paling merata diantara Negaranegara OECD. Tercatat 10\% orang terkaya di Denmark hanya memperoleh pendapatan sebanyak 5,2 kali dari rata-rata jumlah pendapatan terkecil 10\% masyarakat paling miskin di Denmark. Angka pemerataan Denmark jauh lebih baik dibanding rasio pemerataan Negara-negara OECD lain yang mana 10\% kelompok masyarakat terkaya mampu memperoleh pendapatan 10 kali lipat dari pendapatan $10 \%$ kelompok masyarakat perekonomian terendah (OECD 2018). Begitu juga berdasarkan koefisien Gini (perbandingan proporsi komulatif populasi dengan proporsi komulatif pendapatan), Denmark pada tahun 2018 mampu mencatatkan angka o,26 atau hanya berada dibawah indeks Gini Islandia, Ceko, Slovenia, dan Slovakia. Begitu pula angka kemiskinan di Denmark relatif sangat rendah dengan rasio kemiskinan total hanya 0,058 serta rasio kemiskinan usia $0-17$ tahun hanya 0,038 pada tahun 2016, menempatkan Denmark sebagai negara dengan tingkat kemiskinan terendah ketiga diantara Negara-negara OECD (OECD 2018). Tingginya angka kesetaraan dan rendahnya angka kemiskinan dibarengi dengan 
perolehan indeks perkembangan manusia yang mana Denmark berada pada peringkat tiga ketiga di dunia. Denmark juga tercatat sebagai negara dengan tingkat indeks kebahagiaan masyarakat tertinggi di dunia. Begitu juga dengan indeks progress sosial dan indeks persepsi korupsi yang mana Denmark bersama dengan Negara-negara Nordik lainnya mencatatkan angka terbaik di dunia (Iqbal dan Todi 2015).

\section{Grafik 3 \\ Perbandingan Rasio Ketidaksetaraan}

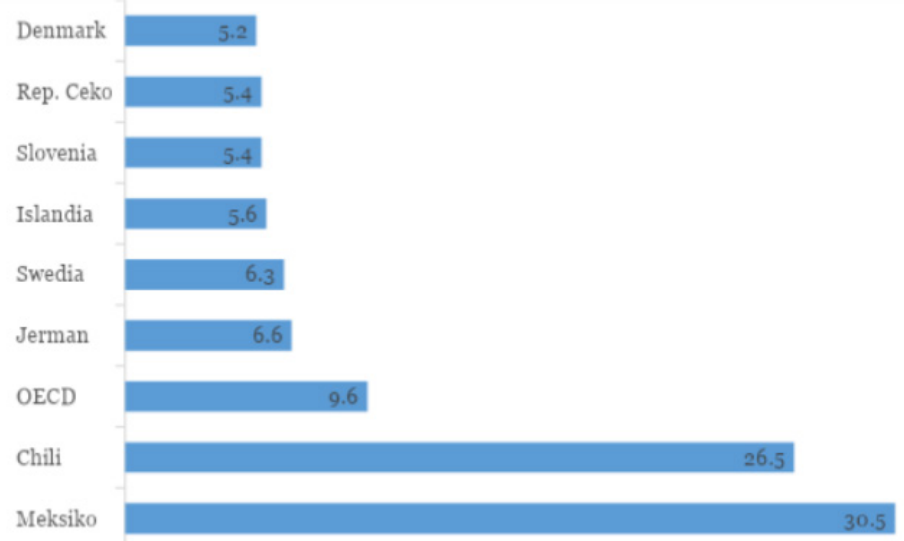

Sumber: OECD (2018)

Pencapaian ekonomi Denmark tidak lepas dari bagaimana prinsip perekonomian Nordik terimplementasi dalam kebijakan perekonomian domestiknya. Seperti halnya Negara-negara Nordik lainnya, Denmark mengimplementasikan prinsip pasar bebas melalui maksimalisasi aktivitas ekspor-impor pada satu sisi diikuti adanya collective sharing guna menunjang manfaat ekonomi dan sosial tersebar pada sektor publik. Pada aspek keterbukaan pasar bebas, Denmark merupakan salah satu negara dengan tingkat keterbukaan ekonomi tinggi. Berdasarkan data Ameco (dalam European Commission 2019), nilai total perdagangan barang dan jasa Denmark pada tahun 2018 mencapai 105 miliar USD, diatas rata-rata pencapaian negara makmur lain seperti Jerman, Swedia, dan Belanda yang berada pada kisaran 95 miliar USD hingga 101 Miliar USD. Sementara itu berdasarkan data WITS nilai ekspor Denmark pada tahun 2017 berkisar 101 Miliar USD 
dengan nilai impor mencapai 92 miliar USD. Dengan demikian Denmark mampu mencapai tingkat rasio perdagangan dengan rataan $103.36 \%$. Keterbukaan terhadap pasar global kemudian ditunjang dengan kebijakan pemerintah dalam mendukung iklim bisnis. Dikutip dari situs Kementerian Luar Negeri Denmark, hal ini dilakukan melalui berbagai penawaran terhadap pelaku bisnis, diantaranya adalah penawaran superior work life balance, ketersediaan tenaga kerja fleksibel, serta iklim pajak korporasi terjangkau diikuti adanya insentif dari sistem welfare-state Denmark. Maka dari itu nilai investasi di Denmark sejak tahun 2010 meningkat signifikan hingga mencapai 25\% dari total GDP tahunan, jauh diatas rata-rata Negara Eropa dengan raihan maksimal 20\% dari GDP tahunan (European Commission 2019).

Keterbukaan ekonomi melalui engagement terhadap perekonomian global didukung peran Pemerintah Denmark dalam melindungi dan mempromosikan kemakmuran ekonomi masyarakatnya. Dikutip dari Kementerian Luar Negeri Denmark, pemerintah berkomitmen terhadap implementasi sistem welfarestate diantaranya melalui jaminan akses terhadap bantuan ketenagakerjaan, jaminan kesehatan publik, dan jaminan pendidikan. Komitmen ini secara sederhana dapat dilihat melalui data jumlah pengeluaran publik Pemerintah Denmark yang mencapai angka 131.00o juta DKK pada tahun 2018 atau sebesar $51,40 \%$ dari total GDP. Sebelumnya Denmark bahkan mampu mencapai titik tertinggi pada kisaran 60\% dari nilai GDP. Nilai tersebut termasuk sangat tinggi apabila dibandingkan negaranegara makmur di Eropa seperti Jerman dengan rasio pengeluaran publik 44\% dari GDP, Belanda dengan rasio 51,30\%, dan Prancis pada kisaran 56\% dari GDP (Trading Economics 2019). Diantara berbagai sektor pengeluaran yang dilakukan, berdasarkan data OECD pengeluaran pada sektor sosial di Denmark memiliki porsi relatif sangat tinggi yaitu berada pada kisaran 28\% dari GDP pada tahun 2018 dan sempat mencapai titik 30\% dari GDP pada tahun 2015. Nilai tersebut menempatkan Denmark sebagai negara dengan tingkat Social Expenditure (SOCX) tertinggi keempat di bawah Prancis, Finlandia, dan Belgia.

Salah satu konsentrasi pengeluaran sosial terbesar adalah pada sektor kesehatan yang mana Denmark merupakan negara dengan 
pengeluaran terbesar pada sektor kesehatan di antara negaranegara OECD. Menurut data Health Management Organisation tahun 2010, pendanaan kesehatan publik di Negara-negara Nordik mencapai angka 80\%, sementara itu di Denmark angka public finance health care mencapai angka $85 \%$, dengan total pengeluaran 10,6\% GDP pada tahun 2015 (The CommonWealth Fund 2015). Sementara itu pada tahun 2019, Denmark tetap memegang status sebagai negara sistem kesehatan terbaik dengan nilai pengeluaran kesehatan publik tertinggi dengan angka 10,2\% dari GDP (OECD 2019). Walaupun demikian pendanaan kesehatan secara privat juga eksis dengan dukungan pemerintah terhadap kehadiran private health insurance yang dapat didanai sendiri oleh masing-masing individu terutama guna membiayai beberapa servis kesehatan yang tidak sepenuhnya dapat ditanggung oleh negara. Tercatat pada tahun 2015 sebanyak 1,5 juta orang di Denmark menggunakan tambahan private health insurance dan angka pendanaan kesehatan secara privat mencapai 20\% dari total pengeluaran kesehatan yang mana $12 \%$ diantaranya merupakan pengeluaran terhadap private health insurance (The Commonwealth Fund 2015).

Data diatas menunjukan peran besar Pemerintah Denmark dalam mendanai kesehatan masyarakat. Prinsip akses universal terhadap kesehatan dalam ketentuan hukum di Denmark mendorong kewajiban pemerintah mendukung secara penuh kebutuhan kesehatan masyarakat termasuk langkah pencegahan, jaminan kualitas perawatan tertinggi, dankesetaraan sertakemudahan akses kesehatan untuk semua. Pemerintah dalam hal ini memiliki andil dalam menentukan serta mengimplementasikan sistem kesehatan nasional di Denmark, meliputi regulasi, perencanaan tersentral, termasuk skema pendanaan penuh dari pemerintah pusat. Secara sederhana dalam sistem kesehatan di Denmark, pemerintah pusat membentuk kerangka regulasi dan sistem perencanaan kesehatan. Lima wilayah administratif memiliki tanggung jawab langsung terhadap implementasi kebijakan dan pendanaan kesehatan masyarakat. Sementara itu elemen administrasi kota bertanggung jawab terhadap pelaksanaan pelayanan kesehatan yang lebih kecil seperti pelayanan kesehatan sekolah, proses rehabilitasi, bantuan pelayanan kesehatan di rumah dan lain-lain (Vrangbek 2015). Dengan demikian sistem kesehatan Denmark merupakan salah 
satu yang terbaik diantara anggota OECD. Bahkan pada tahun 2019, Pemerintah Denmark melakukan intensifikasi pelayanan kesehatan dengan memperbanyak jumlah dokter umum dan perbaikan akses kesehatan masyarakat. Selain itu pada kebijakan ini perawat juga lebih dilibatkan dalam proses promosi kesehatan. Pemerintah juga secara berkelanjutan melakukan investasi dengan mendanai proses pendidikan tenaga kesehatan pengembangan digital health sehingga dewasa ini Denmark dikenal sebagai negara dengan kemajuan sistem e-health terbaik di dunia (OECD 2019).

Subsidi tinggi pemerintah terhadap bidang pendidikan merupakan salah fitur utama penerapan model ekonomi Nordik di Denmark. Pada tahun 2012 rata-rata negara OECD memiliki persentase pengeluaran publik per GDP sebesar 5,8\%, sementara negaranegara Nordik mencatatkan rasio rata-rata sebesar 7\% dari GDP. Denmark dalam bidang ini merupakan negara dengan tingkat pengeluaran publik terhadap edukasi tertinggi dengan rasio pengeluaran sebesar 8\% dari GDP tahunannya. Walaupun terdapat pemotongan anggaran subsidi pendidikan menjadi 7\% dari GDP tahun 2017, akan tetapi Denmark tetap merupakan negara dengan pengeluaran anggaran edukasi tertinggi mencapai 19 miliar EUR. Jumlah tersebut diantaranya dialokasikan bagi pendidikan usia dini sebesar $1,3 \%$ dari GDP atau hanya berada di bawah Swedia yang mengalokasikan 2\% GDP bagi investasi pendidikan usia dini. Pada ranah pendidikan premier hingga sekunder persentase pengeluaran Denmark mencapai 4,7\% GDP dan 1,6\% dari GDP untuk pendidikan tersier. Data tersebut menempatkan Denmark pada jajaran negara dengan pengeluaran publik terhadap edukasi tertinggi.

Pengembangan pendidikan merupakan prioritas utama bagi Pemerintah Denmark. Menurut data OECD, Pemerintah Denmark melakukan investasi sumber daya publik besar terhadap sektor pendidikan dan memprioritaskan pendanaan berdasarkan kebutuhan masyarakat lokal. Pengeluaran pada semua level edukasi merupakan yang tertinggi dengan tingkat keterlibatan pendanaan privat yang sangat minim apabila dibandingkan dengan rata-rata Negara-negara OECD. Biaya pendidikan oleh pemerintah negara tersebut meliputi $98 \%$ pendidikan anak diatas empat tahun. Wujud komitmen Pemerintah Denmark terhadap 
ranah pendidikan juga dapat dilihat dari penentuan gaji pengajar di Denmark. Berdasarkan data Statista pada tahun 2014, gaji tahunan guru elementary school mencapai 45 ribu USD atau berada di urutan ketiga terbesar di dunia. Sementara rata-rata gaji primary dan secondary school mencapai 51 ribu USD atau tertinggi ketujuh diantara Negara-negara OECD. Melalui sistem pendanaan pendidikan secara maksimal, torehan performa pendidikan Denmark dapat dikatakan sangat baik dengan indeks PISA tertinggi di dunia utamanya pada sektor pendidikan matematika. Begitu pula tingkat penyerapan tenaga kerja tahunan terhadap lulusan dapat mencapai rasio 88\%, tertinggi diantara Negara-negara Uni Eropa lainnya. Kualitas pendidikan Denmark kemudian diperkuat dengan adanya kebijakan reformasi pendidikan pada tahun 2018 meliputi efisiensi jam belajar dan mata ajar pada sekolah level menengah dan perubahan orientasi berbasis teknologi dan informasi pada disesuaikan dengan kebutuhan pasar tenaga kerja dewasa ini (OECD 2019).

Optimalisasi sistem edukasi kemudian diikuti dengan catatan apik pada sektor ketenagakerjaan Denmark. Pada tahun 2018 tingkat serapan tenaga kerja Denmark relatif tinggi mencapai 76,9\% atau diatas rata-rata keterserapan tenaga kerja Uni Eropa yaitu $72 \%$. Begitu juga dengan adanya tren penurunan tingkat pengangguran di Denmark. Pada tahun 2017 tingkat pengangguran Denmark sebesar 5,7\%, angka ini kemudian menurun pada kisaran 3,8\% pada tahun 2018 atau jauh di bawah rata-rata tingkat pengangguran Uni Eropa sebesar 7\%. Performa ketenagakerjaan diikuti dengan tingkat gaji tinggi mencapai 5,5 ribu EUR per bulan. Angka ini berada di atas nilai rata-rata gaji di negaranegara Uni Eropa seperti Prancis sebesar 2,9 ribu EUR, Jerman 3,9 ribu EUR, dan Italia 2,4 ribu EUR tiap bulannya. Torehan ini merupakan dampak dari sistem penetapan gaji tinggi yang berlaku di Denmark. Berbeda dengan negara lainnya yang menerapkan sistem gaji minimum, Denmark bersama Negara-negara Nordik lainnya tidak menetapkan gaji minimum secara nasional, melainkan melalui rataan jumlah dari kesepakatan serikat buruh yang kemudian menjadi acuan gaji efektif minimum yakni sebesar 110 DKK tiap jam atau 17 ribu DKK tiap bulan bagi pekerja waktu penuh. Pemerintah juga mampu memberikan jaminan terhadap keuntungan pensiun pekerja. Tercatat Denmark merupakan 
negara dengan tingkat keuntungan pensiun tertinggi dengan persentase total sebesar $74 \%$ dari rata-rata pendapatan pekerja. Tingkat unemployment benefit Denmark juga berada pada level tertinggi diatas rata-rata Uni Eropa dari segi kuantitas, kualitas, dan net replacement rate (OECD 2019).

Konsistensi performa ketenagakerjaan Denmark tidak dapat dilepaskan dari penerapan sistem Felexcurity sebagai model pasar ketenagakerjaan Denmark. Model ini memiliki tiga elemen inti, pertama adalah bahwa pemilik perusahaan dapat merekrut dan memecat pegawai tanpa adanya tanpa adanya biaya tinggi. Akan tetapi setiap pegawai selama bekerja secara kolektif ikut serta membayar tabungan (unemployment insurance funds) yang nantinya berlaku sebagai unemployment benefit apabila pensiun ataupun kehilangan pekerjaannya. Selain itu Pemerintah Denmark juga bertanggung jawab terhadap edukasi dan pelatihan kembali terhadap tenaga kerja yang telah dipecat agar siap kembali bekerja. Sistem Felexcurity dibangun dari tradisi dialog kolektif antara asosiasi employer dengan serikat buruh, sehingga perihal gaji dan situasi kerja dibangun berdasarkan kesepakatan dari negosiasi kolektif diantara keduanya dengan intervensi pemerintah secara terbatas. Denmark juga menyediakan biaya penghidupan bagi masyarakat yang kehilangan pekerjaan akibat sakit, pemecatan, dan bekas pekerja lainnya yang tidak memenuhi syarat mendapatkan keuntungan pensiun berdasarkan skema social welfare (Denmark.dk 2019). Pada tahun 2018 pemerintah Denmark berkomitmen dalam menunjang kesetaraan peluang kerja bagi kaum disabilitas melalui pengeluaran sebesar 120 juta DKKguna menerapkan prioritas kebijakan seperti, pengembangan pengetahuan dan pelatihan kerja bagi kaum disabilitas.

Tingginya pengeluaran publik guna menunjang skema welfarestate, Pemerintah Denmark relatif memberlakukan tarif pajak tinggi sebagai salah satu sumber utama pendanaan negara. Dapat dilihat pada grafik 4, pada tahun 2014 angka pajak pendapatan di Denmark mencapai 55,6\% dari total perolehan pendapatan negara. Persentase tersebut berada di atas rata-rata pajak pendapatan dunia sebesar 31\%, Uni Eropa 32\%, dan OECD 41\%. Pada tahun 2016 tercatat adanya kenaikan pajak pendapatan menjadi 55,8\% kemudian bergerak konstan hingga pada tahun 2018. Penetapan 
pajak pendapatan tinggi kemudian diikuti persentase social security rate sebesar 8\% sejak tahun 2000 hingga tahun 2018. Sementara itu pajak korporasi di Denmark ditetapkan pada rata-rata negara Uni Eropa sebesar 22\% (Trading Economics 2019). Dalam sistem perekonomian Denmark, pajak menjadi sumber pendapatan penting bagi pemerintah sebagai sumber pendanaan utama bagi pelaksanaan berbagai program sosial meliputi bantuan dana, pendidikan, kesehatan, dan keuntungan terhadap tenaga kerja. Seperti halnya di negara lain, sistem pajak di Denmark bersifat progresif yang mana semakin tinggi pendapatan maka semakin besar pajak yang dikenakan. Akan tetapi dengan pajak tinggi, terdapat jaminan keamanan sosial dari pemerintah terhadap seluruh masyarakat. Hal ini berbeda dengan negara lain yang tarif pajak yang lebih kecil namun masyarakat tetap harus membiayai kebutuhan publik dasar seperti kesehatan dan pendidikan secara pribadi (Skat.dk 2019).

\section{Grafik 4 \\ Tarif Pajak Pendapatan di Denmark}

Pajak Pendapatan Denmark

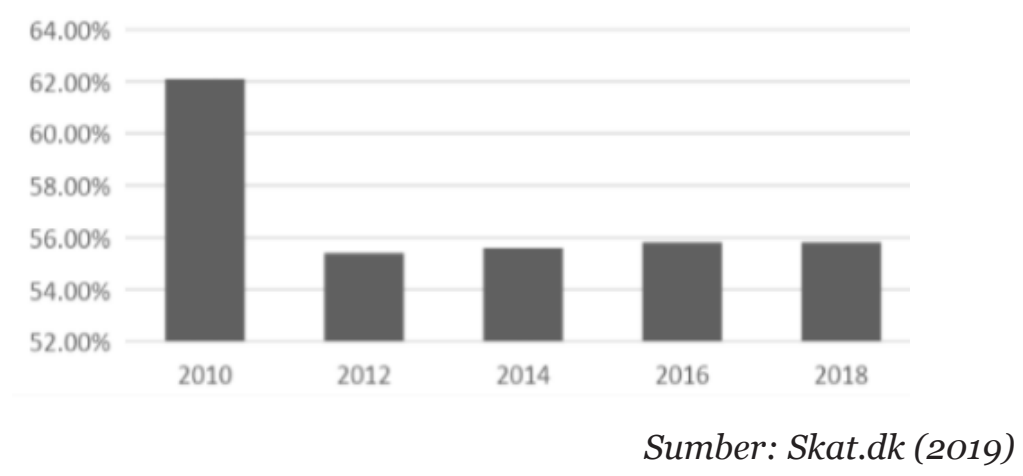

Melalui pendapatan pajak, Pemerintah Denmark memberikan akses setara terhadap berbagai pelayanan publik. Dengan biaya pajak seluruh masyarakat Denmark memperoleh bantuan penuh ketika dihadapkan pada permasalahan seperti sakit hingga pemutusan hubungan kerja. Seluruh anak juga memperoleh akses pendidikan penuh secara merata dan seluruh masyarakat 
memiliki akses penuh terhadap informasi serta pelayanan publik lainnya. Sistem pajak Denmark terbagi menjadi dua yaitu pajak langsung dan pajak tidak langsung. Pajak langsung meliputi pajak pendapatan langsung, pajak pendapatan tidak langsung, pajak negara, pajak kota, biaya kontribusi kesehatan, pajak gereja, serta pajak properti. Bagi kelompok masyarakat pekerja, pajak langsung meliputi biaya kontribusi pasar tenaga kerja (AM-bidrag), dan kontribusi dana pensiun tambahan pasar tenaga kerja Denmark (ATP contribution) (Skat.dk 2018). Sementara itu pajak tidak langsung merupakan pajak dan kewajiban yang dibayarkan melalui pembelian barang dan jasa yang dilakukan. Jenis pajak ini meliputi VAT yaitu pajak seluruh kepemilikan barang, pajak impor barang serta pajak terhadap barang bawaan dari luar negara Uni Eropa. Selain itu masyarakat juga dikenakan pajak lingkungan dari pengeluaran sumber daya masyarakat (Skat.dk 2018).

Guna memperkuat sistem administrasi dan improvisasi pajak, pada Juli tahun 2018 Pemerintah Denmark mereformasi SKAT sebagai lembaga pajak dan cukai menjadi tujuh agensi langsung meliputi agensi pajak, agensi cukai, agensi hutang, agensi valuasi, agensi perkembangan, agensi administrasi dan jasa, dan agensi kendaraan. Bersamaan dengan ini pemerintah Denmark telah menaikan biaya administrasi pajak sebesar 12 miliar DKK dalam tiga tahun yakni, 5 milyar DKK pada tahun 2017 dan 2018 serta sebesar 2,1 milyar pada awal tahun 2019 (OECD 2019). Selain itu perekonomian Denmark sejak tahun 1962 didukung oleh empat institusi ekonomi independen meliputi pertama, Economic Council guna memonitor dan menganalisis perkembangan ekonomi. Kedua, Fisical Independent Institution berfungsi menilai kesehatan pendanaan publik dan ketaatan terhadap hukum budget. Ketiga, National Productivity Board sebagai pihak yang memantau dan menganalisis produktivitas. Terakhir adalah Environmental Council sebagai pihak yang menganalisis keterkaitan antara ekonomi dan aspek lingkungan (OECD 2019).

\section{Simpulan}

Berdasarkan uraian diatas dapat ditarik kesimpulan bahwa demokrasi ekonomi dapat diimplementasikan melalui model 
perekonomian negara-negara Nordik. Implementasi model perekonomian ini selaras dengan tujuan demokrasi ekonomi yaitu terwujudnya kesetaraan dan keadilan sosial dan ekonomi bagi seluruh masyarakat. Dalam sistem ekonomi Nordik terdapat empat prinsip umum, pertama adalah sistem welfare-state, bahwa negara memperhatikan adanya transfer serta distribusi kekayaan terhadap sektor pelayanan publik melalui pemberlakuan pajak pendapatan dan konsumsi. Kedua, pengeluaran ekonomi terbesar negara-negara ini diarahkan pada sektor human capital, salah satunya adalah pendidikan, kesehatan, serta pengembangan sumber daya. Ketiga adalah adanya persatuan kelompok buruh dan pekerja yang terasosiasi dengan kuat serta dilibatkan secara signifikan dalam proses perekonomian negara. Keempat adalah adanya kebijakan collective sharing dalam derajat tinggi sebagai komitmen negara mewujudkan equality secara ekonomi dan sosial. Seperti prinsip demokrasi ekonomi, model ekonomi Nordik merupakan moderasi di antara kapitalisme dan sosialisme. Pada satu sisi terdapat penerapan ekonomi sesuai arus globalisasi dan neoliberalisme ekonomi melalui proses perdagangan bebas. Akan tetapi terdapat sistem proteksi sosial dan distribusi kekayaan layaknya negara sosialis guna melindungi hak sosial dan ekonomi seluruh masyarakatnya.

Perekonomian Denmark menjadi salah satu bentuk keberhasilan penerapan demokrasi ekonomi. Denmark merupakan negara dengan tingkat keterbukaan ekonomi tinggi seiring dengan ketergantungan terhadap aktivitas ekspor dan impor. Hal ini kemudian didukung dengan eksistensi Denmark sebagai negara dengan tingkat pemerataan ekonomi tertinggi di dunia. Selain itu Denmark juga memiliki tingkat kemiskinan terendah ketiga di dunia sejalan dengan kualitas pembangunan sosial mumpuni. Capaian ini merupakan hasil dari sistem welfare-states Denmark dengan subsidi penuh terhadap masyarakat dari kesehatan, edukasi, hingga jaminan ketenagakerjaan. Pendanaan sosial besar ini diperoleh melalui penetapan pajak tertinggi mencapai $55 \%$ dari penghasilan total individu. Biaya yang terbayarkan ini kemudian didistribusikan dalam keseluruhan pelayanan sosial dan ekonomi yang dibutuhkan oleh masyarakat Denmark. Pembelajaran yang dapat diambil dalam pembahasan ini adalah bahwa demokrasi ekonomi sebagai sistem alternatif terhadap kapitalisme global 
pada kenyataannya dapat terimplementasikan di Denmark dan negara Nordik lainnya. Denmark dapat menjadi contoh bagi negara-negara dunia mengenai bagaimana melakukan proteksi dan keadilan ekonomi dan sosial bagi masyarakat di tengahtengah perekonomian dunia yang semakin kapitalis. Terutama bagi negara-negara dunia ketiga, Denmark memberikan pelajaran bahwa intervensi ekonomi dalam sistem kapitalisme global oleh negara harus efisien dan tepat sasaran yaitu untuk melindungi kepentingan masyarakat, menjamin kebutuhan sosial dan ekonomi masyarakat, menyediakan peluang ekonomi merata bagi masyarakat, bukan justru menyebabkan oligarki dan disparitas sosial ekonomi yang semakin tajam siantara masyarakat.

\section{Referensi}

\section{Buku dan Bab dalam Buku}

Andersen, Torben M. et al., 2007. The Nordik Model Embracing Globalization and Sharing Risk. Taloustieto Oy.

Malleson, Tom, 2014. After Occupy, Economic Democracy for the 21st Century. Oxford University Press.

Pikety, Thomas, 2014. Capital in Twenty First Century. London: The Belknap Press of Harvard University Press.

Vrangbaek, Karsten, 2019. The Danish Health Care System. International Commonwealth Fund.

\section{Jurnal dan Jurnal Daring}

Einhorn, Erick S, dan John Logue, 2004. "Can Scandinavian Model Adapt to Globalization?”, dalam Scandinnavian Studies. Vol. 76, No. 4, pp. 504-534.

O’Neill, Martin, 2009. "Liberty, Equality and Property-Owning Democracy", dalam Journal of Social Philosophy, Vol. 40 no. 3, pp. 379-396. 


\section{Artikel Daring}

Dorfman, Jeffrey, 2018. Nordik Countries are not Socialist [daring]. dalam https://www.forbes.com/sites/ jeffreydorfman/2018/07/08/sorry-bernie-bros-butNordik-countries-are-not-socialist/\#336od6c974ad [diakses 16 Oktober 2019].

Denmark.dk, 2018, The Danish Labour Market [daring]. dalam https://denmark.dk/society-and-business/the-danishlabour-market [diakses Pada 16 Oktober 2019].

European Commission, 2019. Country Report Denmark 2019 [pdf]. dalam https://ec.europa.eu/info/sites/info/files/ file import/2019-european-semester-country-reportdenmark en.pdf [diakses pada 20 oktober 2019].

Heritage Foundation, 2019. Denmark Index of Economic Freedom [daring]. dalam https://www.heritage.org/index/ country/denmark [diakses Pada 17 Oktober 2019].

Iqbal, Razi dan Padma Todi, 2015. The Nordik Model: Existence Emergence and Sustainability [pdf]. dalam https://www.sciencedirect.com/science/article/pii/

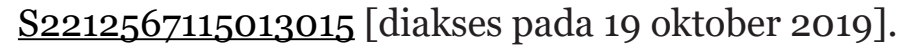

Lykketoft, Mogens, 2009. The Danish Model [pdf]. dalam http:// library.fes.de/pdf-files/id/ipa/06899.pdf [diakses pada 18 oktober 2019].

Matthews, Dylan, 2019. Are 26 Billionaires Worth More than Half of the Planet [daring]. dalam https://www.vox.com/ future-perfect/2019/1/22/18192774/oxfam-inequalityreport-2019-davos-wealth [diakses Pada 15 Oktober 2019].

OECD, 2019. OECD Economic Survey 2019: Denmark [pdf]. dalam http://www.oecd.org/economy/denmark-economicsnapshot/ [diakses pada 16 Oktober 2019]. 
OECD Data, 2019. Social Spending [daring]. dalam https://data. oecd.org/socialexp/social-spending.htm [diakses Pada 16 Oktober 2019]

OECD Data, 2019. Public Spending on Education [daring]. dalam https://data.oecd.org/eduresource/public-spending-oneducation.htm\#indicator-chart [diakses pada 17 Oktober 2019].

Skat.dk, 2018. Tax Rates in Denmark [daring]. dalam https:// skat.dk/skat.aspx?oid $=2035568 \& n$ ext $=2016$ \&lang $=$ US\&tab $=3$ [diakses pada 17 Oktober 2019].

Skat.dk, 2018. Taxation in Denmark [daring]. dalam https:// www.skat.dk/SKAT.aspx?oId $=2244281 \& v I d=0$ [diakses pada 17 Oktober 2019].

Trading Economics, 2018. Tarif Pajak Individu Denmark [daring]. dalam https://id.tradingeconomics.com/ denmark/personal-income-tax-rate [diakses pada 17 Oktober 2019].

Trading Economics, 2019. Denmark GDP Per Capita [daring]. dalam https://tradingeconomics.com/denmark/gdpper-capita [diakses pada 17 Oktober 2019].

World Integrated Trade Solution, 2017. Denmark Trade Summary [daring]. dalam https://wits.worldbank.org/ CountryProfile/en/Country/DNK/Year/LTST/Summary [diakses pada 16 Oktober 2019]. 